\title{
HUBUNGAN BURNOUT DENGAN WORK-LIFE BALANCE PADA DOSEN WANITA
}

\author{
Achmad Amrullah Yoga Priyo Darmawan, Ika Adita Silviandari, Ika Rahma Susilawati \\ achmadamrullahypd@gmail.com
}

\author{
Program Studi Psikologi, Fakultas Ilmu Sosial dan Ilmu Politik \\ Universitas Brawijaya
}

\begin{abstract}
ABSTRAK
Penelitian ini bertujuan untuk melihat hubungan antara burnout dan work-life balance pada dosen wanita. Responden dalam penelitian ini adalah dosen yang mengajar di Universitas Negeri di Kota Malang. Teknik pengambilan data yang digunakan adalah quota sampling dengan komposisi 14 orang dari Universitas Islam Negeri Maulana Malik Ibrahim, 40 orang dari Universitas Negeri Malang, dan 44 orang dari Universitas Brawijaya. Data diperoleh melalui dua alat ukur, yaitu skala burnout yang disusun oleh Kusuma (2013) berdasarkan teori Greenberg (2002) dan skala work-life balance dari Fisher, Bulger, \& Smith (2009) yang telah ditransadaptasi oleh Silviandari, dkk (2014). Hasil analisis memperlihatkan nilai koefisien korelasinya adalah ( $\mathrm{r}$ ) -0.563 dengan $\mathrm{p}=0.000$ yang menunjukkan bahwa terdapat hubungan antara kedua variabel yang bersifat negatif dan berada pada rentang sedang. Hal ini berarti semakin tinggi nilai burnout maka semakin rendah nilai work-life balance. Begitu pula sebaliknya semakin rendah nilai burnout maka semakin tinggi nilai work-life balance.
\end{abstract}

Kata Kunci: Burnout, Work-Life Balance, Dosen Wanita

Kajian tentang wanita saat ini semakin menarik untuk dibahas. Jika dahulu peran wanita identik dengan pekerjaan rumah, saat ini mereka bisa berperan di luar rumah dan merintis karir. Wanita yang memilih untuk bekerja bukan hanya wanita yang masih berstatus lajang, para wanita yang sudah berkeluarga dan mempunyai anak juga banyak yang memutuskan untuk tetap bekerja dan merintis karir. Seperti berita yang dilansir oleh liputan 6 (2014) tentang survei yang dilakukan oleh konsultan manajemen Accenture. Hasil survei tersebut menunjukkan bahwa $42 \%$ wanita di Indonesia lebih memilih untuk bekerja daripada diam di rumah, meskipun mereka tidak mengalami kesulitan ekonomi.
Ada beberapa faktor yang membuat wanita memutuskan untuk bekerja dan menjadi wanita karir. Kartono (Ananda, 2013) menyebutkan hal yang melatar belakangi wanita untuk bekerja, yaitu motif ekonomi, ingin membina karir, dan kesadaran bahwa pembangunan memerlukan tenaga kerja baik pria maupun wanita.

Pekerjaan menjadi pengajar dianggap cocok dengan naluri perempuan sebagai pengasuh anak (Khilmiyah, 2012). Perempuan lebih tepat menjadi pengajar karena stereotip mereka yang sabar dan suka melayani, selain sabar mereka juga luwes, dan berjiwa pendidik (Jatiningsih \& Setyowati, 2006). Dari penjelasan tersebut, maka pekerjaan yang cocok bagi perem- 
puan adalah sebagai pengajar, bisa di tingkat pendidikan dasar (guru) maupun di pendidikan tinggi (dosen).

Di antara para pengajar wanita, dosen memiliki karakteristik tersendiri dimana dosen dipandang sebagai komunitas yang memiliki intelektualitas dan pengetahuan yang relatif baik. Mereka juga dianggap sebagai wanita yang memiliki kemandirian, memiliki sense of self dan kebanggaan diri melalui profesinya (Yuliati, 2012).

Semakin dosen berkompeten maka akan semakin berkualitas lulusan-lulusan yang dapat dicetak, dan semakin bermutu kualitas pendidikan di Indonesia. Kompetensi yang dimiliki dosen juga akan menentukan karir dosen itu sendiri. Hal ini membuat dosen dituntut untuk selalu meningkatkan kompetensi untuk melaksanakan tugas dan tanggung jawabnya. Kemampuan individu untuk melaksanakan tugas dan tanggung jawab merupakan hal yang penting bagi kesuksesan karirnya, namun jika tugas dan tanggung jawab yang dipikulnya dirasa terlalu berat maka dapat menimbulkan stress pada individu yang bersangkutan (Cahyolaksono, 2008). Menurut Freeman, seorang professor di bidang psikologi, wanita lebih rentan untuk mengalami stress emosional. Tuntutan dari lingkungan mereka lebih besar daripada laki-laki. Kesan sempurna adalah ketika wanita bisa menjaga keluarga, karir, penampilan, bahkan merangkap mencari nafkah (Anna, 2013). Stress kerja yang berkepanjangan akan menyebabkan seorang individu mengalami burnout.

Menurut Greenberg (2002) burnout adalah reaksi dari stres kerja baik secara psikologis, psikofisiologis dan perilaku yang bersifat merugikan. Burnout merupakan suatu hal kompleks yang dapat dilihat dari reaksi secara psikologis, pikiran, fisik dan tingkah laku atas suatu pekerjaan, sehingga dapat merugikan individu dan juga organisasi. Adapun gejala-gejela burnout menurut Greenberg (2002) adalah : 1) berkurangnya selera humor (diminished sense of humor), 2) mengabaikan waktu istirahat (skipping rest and food breaks), 3) kerja terus menerus (increased overtime and no vacation), 4) mengalami sakit secara fisik (increased physical complaints), 5) menarik diri dari lingkungan social (social withdrawal), 6) menurunnya kinerja (changed job performance), 7) menggunakan obatobatan (self medication), 8) merubah kepribadian (internal changed)

Burnout bisa terjadi karena beberapa faktor. Maslach, Schaufeli \& Leiter (2001) menjelaskan faktor yang bisa menyebabkan burnout dibagi menjadi dua, yaitu faktor situasional (situasional factor) dan faktor individu (individual factor). Faktor situasional dibagi menjadi Job characteristic,

Occupational characteristic, dan Organizational characteristic. Faktor individual, terdiri dari Demograpic characteristic, Personality characteristic, dan Job attitudes

Maslach (Purba, Yulianto \& Widyanti, 2007) menjelaskan burnout adalah stress yang dialami individu yang pekerjaannya berhadapan secara langsung dengan manusia sebagai penerima pelayanan. Dosen selaku civitas akademika dalam setiap aktivitasnya pasti akan mengadakan kontak langsung dengan individu-individu lain, seperti dalam bentuk pertemuan rapat secara periodik dengan atasannya, hubungan rekan kerja dengan sesama dosen dan staf administasi 
secara rutin maupun interaksi antara dosen dengan mahasiswa dalam bentuk perkuliahan, seminar, bimbingan dan hubungan dalam bentuk lainnya (Tamaela, 2011).

Saat ini sulit membedakan antara kehidupan kantor dan rumah. Dahulu, ketika di kantor seorang karyawan dituntut untuk rasional dan terorganisir, dan sisi emosional seseorang hanya bermain saat mereka berada di rumah. (liputan 6, 2012). Perkembangan teknologi komunikasi saat ini membuat komunikasi bisa dilakukan melalui berbagai cara, seperti chatting dan e-mail, sehingga membuat orang tetap berhubungan dengan rekan kerja mereka dan membicarakan tentang pekerjaan meskipun mereka berada di luar kantor.

Fisher, Bulger, \& Smith (2009) menjelaskan bahwa ketika pekerjaan sudah mengintervensi atau mencampuri kehidupan pribadi maka akan mengganggu keseimbangan kehidupan kerja (work-life balance) para karyawan. Fisher (2001) mendefinisikan work-life balance sebagai upaya yang dilakukan oleh individu untuk menyeimbangkan dua peran atau lebih yang dijalani. Marks \& MacDermid (Greenhaus, Collins \& Shaw, 2003) menjelaskan keseimbangan ini sebagai kecenderungan untuk sepenuhnya terlibat dalam setiap peran yang ada dalam hidup seorang individu, dan melaksanakan setiap peran yang ada dengan penuh perhatian.

Work-life balance merupakan hal yang sangat penting bagi organisasi dan individu. Dikutip dari Djajendra (2013) yang ditulis di harian kompas, work-life balance dapat menciptakan etos kerja yang unggul. Ketika keseimbangan dalam pekerjaan dan kehidupan berada di tingkat kepuasan yang tinggi, maka saat itu etos kerja akan menjadi lebih berkualitas, untuk memberikan kontribusi dan pelayanan terbaik.

Work-life balance merupakan hal yang penting dalam kehidupan manusia. Tidak dapat dipungkiri untuk mewujudkan keseimbangan tersebut tidaklah mudah, ada beberapa hal yang bisa mengganggu keseimbangan ini, salah satunya adalah burnout. Semua bidang pekerjaan memiliki resiko terjadinya burnout, tidak terkecuali dosen. Burnout sendiri diawali dengan munculnya stress kerja yang berkepanjangan. Tidak adanya "balance" atau keseimbangan antara kehidupan dan pekerjaan juga akan berakibat pada burnout (Netemeyer, Boles \& McMurrian, 1996). Penelitian yang sudah ada menjelaskan bahwa burnout lebih rentan terjadi pada wanita mereka lebih memiliki banyak konflik peran yang menyebabkan wanita rentan mengalami kelelahan emosional.

Berdasarkan pemaparan di atas, maka peneliti tertarik untuk melihat hubungan antara burnout dengan work-life balance pada dosen wanita. Adapun hipotesis penelitian adalah terdapat hubungan antara burnout dengan work-life balance pada dosen wanita.

\section{METODE}

\section{Partisipan}

Jumlah sampel yang dalam penelitian ini berjumlah 98 orang dosen yang terdiri dari 14 orang dosen dari Universitas Islam Negeri Maulana Malik Ibrahim (UIN Maliki), 40 orang dosen dari Universitas Negeri Malang (UM), dan 44 orang dosen dari Universitas Brawijaya (UB) yang diperoleh dengan menggunakan teknik quota sampling. 


\section{Desain Penelitian}

Metode penelitian yang digunakan dalam penelitian ini adalah metode penelitian kuantitatif korelasional, yaitu penelitian yang bertujuan menguji keterkaitan antara variabel-variabel yang diteliti yang didasarkan pada hipotesis yang telah ditetapkan (Sumintono \& Widhiarso, 2013). Variabel dalam penelitian ini terdiri dari variabel bebas (burnout) dan variabel terikat (work-life balance).

\section{Instrumen Penelitian}

\section{Skala Burnout}

Skala burnout merupakan modifikasi dari Kusuma (2013) dengan try out terpakai, dimana aitem-aitem yang lolos dalam analisis aitem saja yang akan digunakan dalam analisis data. Setelah dilakukan analisis aitem didapatkan hasil dari 45 aitem yang ada terdapat 24 aitem yang lolos dengan nilai reliabilitas cronbach alpha 0.901 .

\section{Skala Work-Life Balance}

Skala work-life balance merupakan skala dari Fisher, Bulger, \& Smith (2009) yang sudah melalui transadaptasi pada penelitian dari Silviandari, Pratiwi, Widyasari \& Rahma (2014) terdiri dari 15 aitem dengan nilai reliabilitas cronbach alpha 0.823 .

\section{Analisis Data}

Tahap analisa data dilakukan dengan melalui uji normalitas One-Sampel Kolmogorov-Smirnov, uji linieritas dengan mencari persamaan garis regresi variabel $\mathrm{X}$ terhadap variabel $\mathrm{Y}$, kriteria pengujian linieritas adalah apabila nilai signifikasi lebih kecil dari 0.05, dan uji hipotesis menggunakan analisis korelasi Product
Moment Pearson dengan bantun program SPSS (Statistical Product and Service Solution) for windows versi 20.

\section{HASIL}

Analisis deskriptif dilakukan dengan cara mengkategorikan subjek penelitian. Tabel analisis deskriptif berdasarkan kategori data demografis subjek penelitian dapat dilihat pada tabel di bawah ini :

Tabel 1.

\begin{tabular}{cccc}
\hline $\begin{array}{c}\text { Analisis } \\
\text { Deskriptif }\end{array}$ & Kategori & Jumlah & $\%$ \\
\hline Pendidikan & S1 & 1 & 1.02 \\
& S2 & 61 & 62.24 \\
Masa Kerja & S3 & 36 & 36.73 \\
& 1-3 Tahun & 15 & 15.31 \\
& 4-6 Tahun & 17 & 17.35 \\
Status & 7 Tahun & 66 & 67.35 \\
Pernikahan & Melum & 24 & 24.49 \\
& Menikah & 74 & 72.45 \\
& Cerai & 3 & $3 . .6$ \\
\hline
\end{tabular}

Analisis deskriptif Berdasarkan Data Demografis

Berdasarkan tabel 1 dapat dilihat jumlah responden dari beberapa kategori. Tidak banyak responden dalam penelitian ini yang memiliki pendidikan tinggi. Pendidikan tinggi yang dimaksud untuk dosen wanita adalah setara S3. Responden dari penelitian ini sebagian besar memiliki masa kerja di atas 7 tahun, kemudian responden terbanyak berstatus Pegawai Negeri Sipil (PNS). Sebagian besar rensponden sudah menikah. Dari responden yang menikah tersebut ada yang sudah memiliki anak dan belum. Para responden ada yang sudah memiliki rumah sendiri, kontrak, dan masih ada yang tinggal di rumah kost. Sebagian besar responden hanya bekerja sebagai dosen saja tanpa memiliki pekerjaan sampingan. 
Selain data demografis, analisis deskriptif juga dilakukan dengan melihat variabel penelitian. Analisis dilakukan dengan membandingkan antara skor hipotetik dan empirik pada tiap-tiap variabel penelitian.

Tabel 2.

Deskripsi Data Variabel Penelitian

\begin{tabular}{cccc}
\hline Variabel & Statistik & Hipotetik & Empirik \\
\hline Burnout & Nilai Minimal & 24 & 29 \\
& Nilai Maksimal & 96 & 74 \\
& Mean $(\mu)$ & 60 & 42.80 \\
& Standar & 12 & 8.86 \\
Work- & Deviasi $(\sigma)$ & & \\
Life & Nilai Minimal & 15 & 33 \\
Balance & Milai Maksimal & 60 & 57 \\
& Standar & 37.5 & 45.86 \\
& Deviasi $(\sigma)$ & 7.5 & 5.02 \\
& & & \\
\hline
\end{tabular}

Dari skor empirik dan hipotetik tersebut, dapat diperoleh gambaran mengenai variabel $\mathrm{X}$ (burnout) dan variabel Y (work-life balance). Untuk mengetahui kategorinya, disusun sebuah norma berdasarkan ketentuan kategorisasi jenjang berdasarkan subjek penelitian (Azwar, 2012). Dengan formula untuk kategori rendah adalah $X<(\mu-\sigma)$. kemudian untuk kategori sedang $(\mu-\sigma) \leq$ $\mathrm{X}<(\mu+\sigma)$ dan untuk kategori tinggi $(\mu+$ $\sigma) \leq \mathrm{X}$.

Berdasarkan perhitungan tersebut, maka pada variabel X (burnout) dengan jumlah subjek 98 orang dosen diperoleh kategorisasi seperti di bawah ini.

Tabel 3.

Norma Variabel Burnout

\begin{tabular}{lccc}
\hline Kategori & $\begin{array}{c}\text { Daerah } \\
\text { Keputusan }\end{array}$ & $\begin{array}{c}\text { Jumlah } \\
\text { Subjek }\end{array}$ & $\mathbf{( \% )}$ \\
\hline Rendah & $\mathrm{X}<48$ & 78 & 79.6 \\
Sedang & $48 \leq \mathrm{X}<72$ & 18 & 18.4 \\
Tinggi & $72 \leq \mathrm{X}$ & 2 & 2 \\
\hline
\end{tabular}

Dari tabel 3 tersebut maka diketahui bahwa burnout untuk kategori rendah sebanyak 78 orang, kategori sedang 18 orang, dan kategori tinggi sebanyak 2 orang.

Untuk variabel Y (work-life balance) dengan jumlah subjek yang sama yakni 98 orang, diperoleh kategorisasi sebagai berikut.

Tabel 4.

Norma Variabel Work-Life Balance

\begin{tabular}{lccc}
\hline Kategori & $\begin{array}{c}\text { Daerah } \\
\text { Keputusan }\end{array}$ & $\begin{array}{c}\text { Jumlah } \\
\text { Subjek }\end{array}$ & $(\boldsymbol{\%})$ \\
\hline Rendah & $\mathrm{X}<30$ & 0 & 0 \\
Sedang & $30 \leq \mathrm{X}<45$ & 49 & 50 \\
Tinggi & $45 \leq \mathrm{X}$ & 49 & 50
\end{tabular}

Dari tabel 4 diketahui bahwa tidak ada subjek yang memiliki skor work-life balance yang termasuk kategori rendah, kemudian untuk kategori sedang dan tinggi memiliki jumlah yang sama yaitu 49 orang masuk dalam kategori sedang dan 49 orang masuk dalam kategori tinggi.

Berikut adalah hasil dari uji normalitas.

Tabel 5.

Hasil Uji Normalitas

\begin{tabular}{ccc}
\hline Variabel & Sig & Ket \\
\hline Burnout & 0.189 & Normal \\
Work-life balance & 0.122 & Normal \\
\hline
\end{tabular}

Berdasarkan uji KolmogorovSmirnov pada variabel burnout, didapatkan taraf signifikansi atau nilai pvalue variabel burnout sebesar 0.189 dan nilai tersebut lebih besar dari $\alpha=0.05$. Dari pengujian tersebut ditunjukkan bahwa residual memiliki distribusi normal. Berikut adalah hasil dari uji linearitas. 
Tabel 6.

Hasil Uji Linearitas

\begin{tabular}{ccc}
\hline Variabel & Sig & Ket \\
\hline $\begin{array}{c}\text { Burnout*Work-Life } \\
\text { Balance }\end{array}$ & 0.000 & Linear
\end{tabular}

Keterangan $:(*)=$ Terhadap

Berdasarkan tabel 6 di atas, dapat diketahui bahwa uji linearitas antara variabel burnout dan work-life balance memiliki nilai $\mathrm{F}$ sebesar 46.297 dengan nilai signifikansi 0.000 yang nilainya lebih kecil dari 0.05. Hasil tersebut menunjukkan bahwa variabel burnout memiliki hubungan yang linier dengan variabel work-life balance. Uji hipotesis menggunakan korelasi Product Moment Pearson. Hasil uji korelasi Product Moment Pearson dapat dilihat pada tabel berikut :

Tabel 7.

Hasil Uji Korelasi

\begin{tabular}{cccc}
\hline Variabel & $\begin{array}{c}\text { Koefisien } \\
\text { Korelasi }\end{array}$ & Sig & Ket \\
\hline $\begin{array}{c}\text { Burnout }{ }^{*} \text { Work- } \\
\text { Life Balance }\end{array}$ & -0.563 & $\begin{array}{c}0.00 \\
0\end{array}$ & Sedang \\
\hline
\end{tabular}

Keterangan : $(*)=$ Terhadap

Dari tabel 7 dapat dilihat bahwa skor koefisien korelasi Product Moment Pearson dalam penelitian ini bernilai 0.563 dengan signifikansi 0.000. Sesuai dengan pedoman interpretasi berdasarkan skor koefisien korelasi Product Moment Pearson, disebutkan bahwa jika skor koefisien korelasi Product Moment Pearson berada pada rentang $0.40-0.599$ berarti hubungan antar variabel dalam penelitian ini termasuk dalam kategori sedang. Skor koefisien korelasi bernilai negatif, ini berarti variabel dalam penelitian ini memiliki hubungan yang saling berkebalikan. Semakin tinggi burnout maka akan semakin rendah worklife balance dan sebaliknya semakin JURNAL PSIKOLOGI MEDIAPSI rendah burnout maka akan semakin tinggi work-life balance.

Setelah didapatkan nilai koefisien korelasi antara variabel burnout dan worklife balance, selanjutnya adalah mencari nilai koefisien determinasi untuk mengetahui presentase hubungan antara kedua variabel. Koefisien determinasi dalam penelitian ini bernilai $31.70 \%$. Ini berarti hubungan variabel burnout dalam mempengaruhi variabel work-life balance sebesar $31.70 \%$ dan sisanya $68.30 \%$ berhubungan dengan faktor lain yang tidak terdapat pada penelitian ini.

Analisis tambahan dengan melakukan uji regresi linier sederhana dan uji beda. Uji regresi linier sederhana dilakukan untuk melihat pengaruh variabel burnout terhadap variabel work-life balance. Dengan hasil sebagai berikut :

Tabel 8.

Hasil Uji Regresi Linier Sederhana

\begin{tabular}{cccc}
\hline R square & Sig. & Koefisien & Ket. \\
0,317 & 0.000 & -6.679 & $\begin{array}{c}\text { Signifi- } \\
\text { kan }\end{array}$ \\
\hline
\end{tabular}

Dari tabel 8 dapat dilihat bahwa nilai signifikansinya adalah 0.000 lebih rendah dari nilai alpha $(\alpha)=0.05$ (Sig. $<0.05)$. Ini berarti bahwa variabel burnout berpengaruh secara signifikan terhadap variabel work-life balance. Nilai $\mathrm{R}$ square adalah 0. 317 yang berarti besarnya pengaruh variabel burnout terhadap variabel work-life balance adalah $31.7 \%$.

Selain uji regresi linier sederhana, dilakukan uji perbedaan untuk melihat apakah terdapat perbedaan tingkat burnout dan work-life balance pada beberapa kelompok penelitian. Hasil uji perbedaan dapat dilihat pada tabel berikut : 
Tabel 9.

Uji Perbedaan Variabel Burnout

\begin{tabular}{cc}
\hline Kelompok uji perbedaan & Sig \\
\hline Status pernikahan & p-value $=0.309$ \\
Masa kerja & -value $=0.538$ \\
Tingkat pendidikan & p-value $=0.563$ \\
\hline
\end{tabular}

Tabel 9 menjelaskan bahwa tidak ada perbedaan yang bermakna pada tingkat burnout dilihat dari status pernikahan, masa kerja, dan tingkat pendidikan ( $p$-value $>0.05)$.

Sedangkan uji perbedaan untuk work-life balance dilakukan berdasarkan status pernikahan dengan hasil sebagai berikut :

Tabel 10.

Uji Perbedaan Variabel Work-Life Balance

\begin{tabular}{cc}
\hline $\begin{array}{c}\text { Kelompok uji } \\
\text { perbedaan }\end{array}$ & Sig \\
\hline Status pernikahan & $p$-value $=0.615$ \\
\hline
\end{tabular}

Dari tabel 10 dapat dilihat bahwa tidak ada perbedaan yang bermakna pada tingkat work-life balance dilihat dari status pernikahan ( $p$-value > 0.05).

\section{DISKUSI}

Hasil dari penelitian ini sesuai dengan hipotesis yang diajukan oleh peneliti bahwa terdapat hubungan antara burnout dan work-life balance pada dosen wanita. Nilai koefisien korelasi menunjukkan nilai negatif (-0.563) sehingga dapat disimpulkan kedua variabel memiliki hubungan linear negatif dan tergolong dalam rentang sedang. Ini berarti semakin tinggi burnout, maka akan semakin rendah work-life balance dan sebaliknya semakin rendah burnout maka akan semakin tinggi work-life balance. Hubungan kedua variabel berada pada rentang sedang yang berarti hubungan keterkaitan antara dua variabel ini berada pada tingkat sedang, tidak kuat dan tidak lemah.

Hasil dari penelitian ini sejalan dengan penelitian yang pernah ada. Penelitian dari Shanafelt,Tait D., Boone, Sonja., Tan, Litjen., Dyrbye, Lotte N., Sotile, Wayne., Satele, Daniel., West, Colin P., Sloan, Jeff., Oreskovich, Michael R (2012) menunjukkan bahwa sebagian besar sampel penelitian (dokter) yang diketahui memiliki gejala-gejala burnout digambarkan memiliki tingkat work-life balance yang rendah, karena jam kerja mereka tidak memberikan cukup waktu untuk kehidupan pribadi maupun waktu untuk keluarga mereka.

Hasil dari penelitian ini memperlihatkan bahwa terdapat hubungan antara burn out dengan work-life balance, yang dijelaskan lebih detil bahwa sebagian besar dosen wanita berada pada tingkat burnout yang rendah dan sedang serta work-life balance tingkat sedang dan tinggi. Untuk variabel burnout, sebagian besar dosen wanita berada pada tingkat burnout rendah, yaitu sebanyak 78 orang (79.6\%), tingkat burnout sedang 18 orang (18.4\%), dan tingkat burnout tinggi hanya 2 orang (2\%).

Burnout rendah yang ditunjukkan responden dalam penelitian ini bisa dijelaskan dengan beberapa faktor. Menurut Maslach, dkk (2001) karakteristik demografis seperti usia dalam hal ini adalah masa kerja, jenis kelamin, tingkat pendidikan, dan status pernikahan bisa berpengaruh terhadap burnout.

Karyawan yang baru bekerja akan lebih cenderung untuk mengalami burnout daripada karyawan yang sudah bekerja 
dalam waktu yang lama. Ini merupakan resiko awal dari karir seseorang (Maslach, et al 2001). Dalam data demografis dapat dilihat bahwa sebagian besar sampel yang memiliki masa kerja di atas 7 tahun berjumlah 66 orang dosen $(67.35 \%), 17$ orang (17.35) memiliki masa kerja antara 4-6 tahun, dan sisanya yaitu 15 orang (15.31) memiliki masa kerja antara 1-3 tahun. Dari data tersebut dapat dilihat bahwa sebagian besar responden memiliki masa kerja di atas 7 tahun.

Berdasarkan tingkat pendidikan, beberapa penelitian menemukan bahwa semakin tinggi tingkat pendidikan, semakin tinggi tingkat burnout. Hal ini dimungkinkan karena seseorang dengan tingkat pendidikan yang lebih tinggi, bekerja dengan tanggung jawab yang lebih besar dan tingkat stress yang tinggi. Dimungkinkan juga bahwa orang yang berpendidikan tinggi memiliki ekspektasi yang lebih tinggi terhadap pekerjaannya dan mereka menjadi lebih tertekan saat ekspektasi tidak terealisasi (Maslach, et al, 2001). Hal ini sejalan dengan data demografis penelitian ini yang menunjukkan bahwa 36 orang dosen (36.73\%) berpendidikan S3, sisanya 61 orang $(62.24 \%)$ memiliki pendidikan $\mathrm{S} 2$, dan 1 orang $(1.02 \%)$ berpendidikan $\mathrm{S} 1$, menunjukkan burnout yang rendah.

Berdasarkan status pernikahan, seseorang yang belum menikah cenderung lebih mudah untuk mengalami burnout dibanding karyawan yang sudah menikah (Maslach, et al, 2001). Data penelitian ini menunjukkan sebagian besar dosen sudah berumah tangga, yaitu 24 orang dosen $(24.49 \%)$ belum menikah, 74 orang $(72.45 \%)$ sudah menikah, dan sisanya 3 orang dosen $(3.06 \%)$ sudah pernah menikah namun mengalami perceraian.
Wills (Purba, et al, 2007) menjelaskan bagi mereka yang lajang, ketidakhadiran pasangan mengurangi kemungkinan untuk mendapatkan dukungan ketika menghadapi masalah. Sebaliknya mereka yang menikah, pasangan hidup merupakan pribadi yang dipandang paling banyak memberi dukungan ketika menghadapi masalah.

Seperti yang dijelaskan di awal pembahasan, bahwa hasil analisis menunjukkan adanya hubungan negatif antara burnout dan work-life balance. Ketika burnout rendah maka work-life balance tinggi. Hasil penelitian memperlihatkan responden berada pada tingkat work-life balance sedang 49 orang (50\%) dan tinggi 49 orang $(50 \%)$ dan tidak ada responden yang berada pada tingkat work-life balance rendah.

Hasil dari penelitian ini memperlihatkan tidak adanya dosen yang masuk dalam kategori work-life balance rendah, 49 orang $(50 \%)$ masuk dalam kategori sedang dan 49 orang (50\%) sisanya masuk dalam kategori tinggi. Hal ini bisa dijelaskan dengan role theory. Fisher (2001) menjelaskan dalam role theory bahwa manusia dipandang sebagai individu yang memiliki banyak peran dalam hiduonya. Dari hasil analisis dapat disimpulkan bahwa dosen wanita yang menjadi sampel dalam penelitian ini memiliki tingkat "balance" yang baik karena mereka bisa menjalankan peranperan yang mereka miliki, sehingga tidak menimbulkan konflik peran dalam kehidupan mereka.

Dalam penelitian ini, terlihat nilai koefisien determinasinya adalah $31.70 \%$. Ini berarti hubungan variabel burnout dalam mempengaruhi variabel work-life balance sebesar $31.70 \%$ dan sisanya 
$68.30 \%$ berhubungan dengan faktor lain yang tidak terdapat pada penelitian ini.

Faktor-faktor lain yang berhubungan dengan work-life balance menurut Schabracq, Winnubst, dan Coope (Novelia, 2013) yang pertama berasal dari karakteristik kepribadian masing-masing karyawan. Faktor kedua adalah perbedaan karakteristik keluarga dimana setiap orang memiliki cara yang berbeda dalam membentuk dan membina keluarga itu sendiri. Ketiga adalah perbedaan karakteristik pekerjaan. Setiap karyawan pasti memiliki perbedaan dalam pola kerja, beban kerja, jumlah jam kerja sampai pada perbedaan resiko adanya konflik kerja. Faktor keempat dan yang terakhir yang mempengaruhi work-life balance yaitu perbedaan sikap dari masing-masing orang dalam memandang work-life balance itu sendiri. Perbedaan mengenai skala prioritas hidup juga membuat tiap orang memiliki pandangan yang berbeda mengenai work-life balance.

Dilihat dari penjelasan tentang kedua variabel tersebut, dan setelah melalui tahap analisa data, maka dapat disimpulkan kedua variabel tersebut memiliki hubungan yang linier dan bersifat negatif. Tingkat burnout yang dialami dosen wanita akan berbanding terbalik dengan keseimbangan kehidupan kerja mereka (work-life balance). Ada beberapa faktor yang berpengaruh, misalnya adalah waktu yang merupakan faktor yang mempengaruhi burnout (Maslach, Te al, 2001). Menurut Fisher (2001) waktu juga merupakan komponen utama dari work-life balance. Arwildayanto menjelaskan pembagian waktu kerja dosen haruslah proporsional dan berkeadilan, tidak boleh terjadi adanya penumpukan beban mengajar ke salah seorang dosen saja. Dikutip dari buku pedoman beban kerja dan evaluasi pelaksanaan tridharma perguruan tinggi tahun 2010, beban kerja dosen paling sedikit sepadan dengan 12 (dua belas) SKS dan paling banyak 16 (enam belas) SKS pada setiap semester sesuai dengan kualifikasi akademik, dan nilai dari 1 SKS tersebut sama dengan 50 menit.

Selain waktu, karakteristik sebuah pekerjaan juga menjadi faktor dari burnout (Maslach, et al, 2001) dan menurut Schabracq, Winnubst dan Coope (Novelia, 2013) karakteristik pekerjaan akan memberikan beban kerja yang berbedabeda sehingga akan mempengaruhi persepsi seorang dosen terhadap work-life balance. Tugas utama seorang dosen adalah mengajar, baik itu pelajaran akademis maupun pelajaran moral. Pekerjaan menjadi pengajar dianggap cocok dengan naluri perempuan sebagai pengasuh anak (Khilmiyah, 2012). Karena stereotipnya yang sabar dan suka melayani serta karakteristik perempuan yang selain sabar juga luwes, dan berjiwa pendidik, perempuan lebih tepat menjadi pengajar (Jatiningsih \& Setyowati, 2006).

Peran ganda yang dimiliki oleh wanita juga berpengaruh terhadap tingkat kelelahan seseorang. Seorang pekerja wanita, dalam kasus ini adalah seorang Dosen wanita dapat menjalankan peran yang berbeda-beda. Hal ini dapat mengakibatkan tuntutan yang berbedabeda pula dari masing-masing peran. Diferensiasi dalam beberapa peran itu dapat menumbuhkan kompetisi dalam menggunakan waktu, energi, perhatian dan komitmen. Hal ini dapat menimbulkan konflik peran perempuan yang berkaitan kelelahan kerja akibat beban kerja yang berat (Nurastuti, 2008). Sejalan dengan 
salah satu model teori dalam work-life balance yang dikemukakan oleh Fisher (2001), yaitu role theory menyebutkan bahwa berdasarkan teori ini, manusia dipandang sebagai individu yang memiliki banyak peran dalam hidupnya, termasuk peran di lingkungan kerja dan peran di luar lingkungan kerja. Adanya berbagai peran yang harus dijalankan ini akan menimbulkan konflik ketika tekanan dari dua atau lebih peran terjadi dalam satu waktu, dan satu peran menghambat pelaksanaan dari peran yang lain.

Dari analisis tambahan terlihat bahwa variabel burnout mempengaruhi variabel work-life balance sebesar $31.7 \%$ kemudian tidak ada perbedaan tingkat burnout yang signifikan pada beberapa kelompok (masa kerja, status pendidikan, dan status pernikahan) serta tidak ada perbedaan work-life balance yang signifikan dilihat dari status pernikahan.

\section{KESIMPULAN}

Dari hasil analisis data, didapatkan kesimpulan yakni terdapat hubungan linier yang negatif antara burnout dengan worklife balance, hal ini berarti semakin tinggi burnout maka akan semakin rendah worklife balance dan sebaliknya.

Responden dalam penelitian ini menunjukkan tingkat burnout yang rendah dan tingkat work-life balance tinggi. Burnout yang rendah tersebut disebabkan karena beberapa faktor, yaitu tingkat pendidikan, masa kerja, dan status pernikahan.

Variabel burnout memiliki sumbangan efektif terhadap terciptanya work-life balance sebesar $31.70 \%$ dan $68.30 \%$ sisanya berhubungan dengan faktor lain yang tidak terdapat pada penelitian ini, seperti karakteristik kepribadian, perbedaan karakteristik keluarga, perbedaan karakteristik pekerjaan, dan perbedaan sikap dari masing-masing orang dalam memandang work-life balance itu sendiri.

Hasil uji beda memperlihatkan bahwa tidak terdapat perbedaan yang bermakna pada tingkat burnout berdasarkan status pernikahan, masa kerja, dan tingkat pendidikan. Hal yang sama juga terlihat pada variabel work-life balance, tidak ada perbedaan yang bermakna pada tingkat work-life balance berdasarkan status pernikahan.

\section{DAFTAR PUSTAKA}

Ananda, M. R. (2013). Self Esteem antara Ibu Rumah Tangga yang Bekerja dengan yang Tidak Bekerja. Jurnal Online Psikologi Vol. 01 No. 01, Thn. 2013

Anna, L.K. (2013). Wanita Lebi Rentan Stres Emosional. http://health.kompas.com/read/2013/ 05/25/08244338/Wanita.Lebih.Renta n.Stres.Emosional diakses pada Selasa, 5 Agustus 2014 pukul 17:05

Arwildayanto. (2012). Manajemen Sumber Daya Manusia Perguruan Tinggi ; Pendekatan Budaya Kerja dosen Profesional. Gorontalo : Ideas Publishing.

Azwar, S. (2012). Reliabilitas dan Validitas. Yogyakarta : Pustaka Pelajar

Azwar, S. (2012). Penyusunan Skala Psikologi. Yogyakarta : Pustaka Pelajar 
Cahyolaksono, S. M. (2008). Stress Kerja pada Dosen Perempuan Ditinjau dari Konflik Peran Ganda dan Dukungan Sosial Suami. Skripsi Mahasiswa Fakultas Psikologi Universitas Katolik Soegijapranata Semarang

Deny, S. (2014). 42\% Wanita RI Lebih Pilih Bekerja Daripada Diam di Rumah.http://bisnis.liputan6.com/rea d/2019532/42-wanita-ri-lebih-pilihbekerja-daripada-diam-di-rumah diakses pada Rabu 20 Agustus 2014 pukul 22:00

Direktorat Jenderal Pendidikan Tinggi Departemen Pendidikan Nasional. (2010). Pedoman Beban Kerja Dosen Dan Evaluasi Pelaksanaan Tridharma Perguruan Tinggi

Djajendra. (2013). Work-Life Balance Menciptakan Etos Kerja yang Unggul.http://ekonomi.kompasiana.c om/manajemen/2013/03/23/worklife-balance-menciptakan-etos-kerjayang-unggul-545200.html diakses pada Jum'at 25 Juli 2014 pukul $10: 30$

Fisher, G. G. (2001). Work / Personal Life Balance: A Construct Development Study. A Dissertation Submitted to the Graduate College of Bowling Green State University in partial fulfillment of the requirements for the degree of Doctor of Philosophy

Fisher, G. G., Bulger, C. A., \& Smith, C. S. (2009). Beyond Work and Family: A Measure of Work/Nonwork Interference and Enhancement. Journal of Occupational Health Psychology 2009, Vol. 14, No. 4, 441-456

Greenberg, J.S. 2002. Comprehensive Stress Management ( $7^{\text {th }}$ Edition). McGraw Hill : New York

Greenhaus, J. H., Collins, K. M., \& Shaw, J. D. (2003). The Relation Between
Work-Family Balance and Quality of Life. Journal of Vocational Behavior 63 (2003) 510-531

Jatiningsih, Oksiana \& Setyowati, Nanik. (2006). Konstruksi Gender Guru di Sekolah Dasar Negeri di Surabaya. LENTERA, Jurnal Studi Perempuan, Vol. 2/No. 1/Juni 2006, ISSN 18584845

Khilmiyah, A. (2012). Stres Kerja Guru Perempuan di Kecamatan Kasihan Bantul Yogyakarta. Lentera Pendidikan, Vol. 15 No. 2 Desember 2012: 135-143

Kusuma, A. P. (2013). Pengaruh LeaderMember Exchange (LMX) dan Organizational Climate (Iklim Organisasi) terhadap Tingkat Burnout Karyawan (Studi pada Kepala Unit dan Karyawan Customer Service BRI Mojokerto). Skripsi (Tidak Diterbitkan). Malang : Program Studi Psikologi Universitas Brawijaya

Liputan 6 . (2012). Karyawan Menangis di Kantor Wajar Nggak? http://health.liputan6.com/read/4587 66/karyawan-menangis-di-kantorwajar-nggak diakses pada Sabtu 23 Agustus 2014 pukul 07:24

Luthans, F. (2006). Perilaku Organisasi edisi 10. Jogjakarta : ANDI

Maslach, C. \& Jackson, S. E. (1981). The Measurement of Experienced Burnout. Journal of Occupational Behaviour, Vol. 2, 99-113 (1981)

Maslach, C., Schaufeli, W. B., Leiter, M. P. (2001). Job Burnout. Annu. Rev. Psychol. 2001. 52:397-422

Mizmir. (2011). Hubungan Bunrout dengan Kepuasan Kerja Pustakawan di Pusat Jasa Perpustakaan dan Informasi Perpustakaan Nasional Republik Indonesia. Skripsi 
DARMAWAN, SILVIANDARI, \& SUSILAWATI

Mahasiswa Program Studi Ilmu Perpustakaan Fakultas Ilmu Pengetahuan Budaya Universitas Indonesia. 